Methods in Microbiology, Extremophiles

2006; VOLUME 35 : Pages 93-108

http://dx.doi.org/10.1016/S0580-9517(08)70007-2

(c) 2006 Elsevier B.V. All rights reserved.
Archimer Archive Institutionnelle de l'Ifremer http://www.ifremer.fr/docelec/

\title{
Growth of hyperthermophilic microorganisms for physiological and nutritional studies
}

\author{
Anne Godfroy ${ }^{1, *}$, Anne Postec ${ }^{1}$ and Neil Raven ${ }^{2}$ \\ ${ }^{1}$ Laboratoire de Microbiologie des Environnements Extrêmes, UMR 6197, Ifremer, BP 7029280, Plouzané, \\ France \\ ${ }^{2}$ Health Protection Agency, Porton Down, Salisbury SP4 0JG, United Kingdom \\ *: Corresponding author : Anne Godfroy, email address : Anne.Godfroy@ifremer.fr
}


Hyperthermophilic microorganisms grow at temperature of $80^{\circ} \mathrm{C}$ and above. Numerous species belonging to both the Archaea and Bacteria have now been isolated from both continental and volcanic areas. Initially following major isolation efforts, heterotrophic species were recovered, but this has now extended to species involved in all geobiochemical cycles and employing a wide range of electron donors and acceptors.

In addition to their ecological and evolutionary interest, these organisms were rapidly identified as potential sources of stable biomolecules having potential application in industrial processes. However, an understanding of their growth characteristics and metabolism is necessary to realize their full biotechnological potential. A major limitation to their study has frequently been the small amount of biomass that can be generated.

Within the archaeal hyperthermophiles, some species have been more extensively studied: 1) thermoacidophilic species belonging to the order Sulfolobales 2) methanogens and 3) a number of species belonging to the order Thermococcales.

A key factor in the study of hyperthermophilic organisms has been the development of cultivation strategies allowing exploration of their metabolic behaviour and the optimisation of their growth parameters. At the same time this has allowed the production of biomass in sufficient quantities for further studies.

Initially, concerns about the damaging effect of highs level of reduced sulphur species by anaerobic hyperthermophiles, or sulphuric acid by oxidizing species, led to the development of multi-hundred litre capacity fermentors with ceramic liners (Kelly and Deming, 1988) Large scale cultivation of hyperthermophilic species was reported by Karl Stetter's group for biomass production of various hyperthermophilic species using an enamelled 300 litre fermentor (Stetter et al., 1983; Blöchl et al., 1997; Huber et al., 2000). A range of cultivation systems have also been reported for the culture of 
acidophilic hyperthermophiles (Schiaraldi et al., 1999; Worthington et al., 2003) and methanogens (Mukhopadhyay et al., 1999).

\section{CULTIVATION OF SULPHUR-REDUCING HYPERTHERMOPHILES IN BIOREACTORS}

The cultivation of microorganisms at temperatures up to $110^{\circ} \mathrm{C}$, in media that may contain high salt concentrations, and that actively produce hydrogen sulphide represents a major challenge to conventional laboratory fermentation equipment.

Thermococcales have been isolated from both deep and shallow marine ecosystems [with the exception of Thermococcus sibiricus (Miroshnichenko et al., 2001) isolated from a high temperature oil reservoir and Thermococcus ziligiii (Ronimus et al., 1997) and Thermococcus waiotapuensis (Gonzalez et al., 1999) isolated from a continental hot spring]. The order Thermococcales includes 3 genera: Thermococcus, Pyrococcus and Paleococcus. These species are all anaerobic; they utilize peptides as carbon and energy sources and most of them exhibit better growth in the presence of elemental sulphur producing large amounts of hydrogen sulphide. Some are able to grow in the absence of elemental sulphur, but in serum vial batch culture the production of molecular hydrogen as a metabolic end product leads to early inhibition of growth.

Within the Thermococcales, the shallow marine species Pyrococcus furiosus has been the most extensively studied in terms of its physiology, genetics and enzymology, and is generally considered as the model species for heterotrophic hyperthermophiles. The pathways of both peptide and carbohydrate metabolism of this species have been well studied (Adams et al., 2001).

Pressurized bioreactors have been developed in consideration that high pressure may be important for the growth of deep sea sulphur-reducing hyperthermophiles (Kelly and Deming, 1988; Miller 
et al., 1988; Nelson et al., 1992). However, most hyperthermophiles have been isolated at atmospheric pressure, although pressure effects have been reported for some of them (Erauso et al., 1993; Marteinsson et al., 1999a; Marteinsson et al., 1999b; Canganella et al., 2000). Simpler and less expensive approaches for the cultivation of hyperthermophiles have also been reported. These have been used successfully both to generate large quantities of biomass and to explore their physiology.

As they are relatively easy to grow, many systems have been developed for the cultivation of Thermococcales species, with particular emphasis on $P$. furiosus. Batch fermentation of numerous sulphur-reducing hyperthermophiles has been reported using conventional stainless-steel bioreactors, with proper attention to cleaning and maintenance operations, and numerous enzymes have been purified from the biomass produced (Adams, 1993; Gantelet and Duchiron, 1998; Raffin et al., 2000). In the presence of sulphur, hydrogen sulphide is produced instead leading to moderate cells densities in closed culture (Fiala and Stetter, 1986; Godfroy et al., 2000). Since hydrogen sulphide is reasonably soluble in water, this can lead to growth inhibition, the absence of a real stationary phase and cell lysis (personal observation). Moreover, reaction with many metals occurs to form extremely insoluble sulphide precipitates. However, high cell densities of Thermococcales can be obtained by sparging sulphur-containing cultures with anaerobic gases such as nitrogen, in both closed vials or in conventional glass fermentors (Brown and Kelly, 1989) or a modified one as described for the cultivation of $P$. abyssi (Godfroy et al., 2000),

The reactor described by Brown and Kelly (Brown and Kelly, 1989) comprised a 2 litre glass round bottomed flask maintained at high temperature by a heating mantle controlled by a proportional controller. The reactor was operated at a volume of 1 litre. The vessel was fitted with a gas inlet sparger and the exit gas was passed through 
sodium hydroxide to remove hydrogen sulphide. The medium was supplied from a polycarbonate reservoir using a peristaltic pump and anaerobicity maintained by sparging with nitrogen. After each change of dilution rate, sulphur was added to ensure it remained in excess. A constant volume was maintained via a dip tube connected in parallel to the medium feed pump.

When grown in the absence of elemental sulphur, species belonging to the order Thermococcales were shown to produce hydrogen as an end product of their metabolism and this appeared to limit growth severely unless removed. The glass continuous culture vessel described by Brown and Kelly (1989) has been used in many studies (Rinker and Kelly, 1996; Rinker and Kelly, 2000) for cultivation of $P$. furiosus, $T$. littoralis and the bacterium Marinitoga maritima.

Fermentation of $P$. furiosus in a conventional stirred bioreactor was described by Krahe et al. (1996) generating a high cell density, but it was shown that stirrer speeds above $1800 \mathrm{rpm}$ had a negative effect on growth. Krahe also reported the utilisation of dialysis membrane bioreactor system for the cultivation of $P$. furiosus (Krahe et al., 1996). Cultivation at high temperature was carried out using a Bioengeenering (Wald, Switzerland) membrane bioreactor consisting of two compartments (Holst et al., 1997). The outer compartment comprises a cylindrical high strength polyamide foil fixed to a top and bottom stainless steel plate. The inner compartment is separated from the outer one by a tubular dialysis membrane. Gas sparging can be applied to either the inner or outer compartment, or both if necessary. The reactor is also equipped with two stirring units. Application of a high medium dilution rate in the outer compartment was shown to permit high cell densities to be reached compared to cultivation in closed glass bottle, primarily by the removal of a range of metabolic end products. This system was also used for cultivation of the thermoacidophilic species Sulfolobus shibatae (Krahe et al., 1996). 
A 2-litre bioreactor has also been developed for the cultivation of $P$. furiosus in continuous culture to high cell concentrations and biomass yields (Raven et al., 1992). The intense sparging of sulphurfree, hydrogen evolving cultures has significant advantages, both in the quality of biomass produced and in the safety of the procedure. Since the risk of contamination of thermophilic and hyperthermophilic continuous cultures is relatively small, long-term steady state experiments both for biomass production and for the detailed investigation of physiological responses to culture perturbation are made possible.

\section{CONTINUOUS CULTURE OF THERMOCOCCALES SPECIES IN THE GLASS GAS-LIFT BIOREACTOR}

This experimental protocol, initially developed for optimisation of biomass production of $P$. furiosus, was then used for the development of a sulphur-free minimal medium for $P$. furiosus (Raven and Sharp, 1997), physiological study of Pyrococcus abyssi strain ST549 (Godfroy et al., 2000), optimisation of culture conditions for the growth of Thermococcus hydrothermalis and the development of defined and minimal media (Postec et al., 2005b). This protocol is now routinely used for biomass production of the Pyrococcus abyssi type strain GE5.

\section{Description of the gas lift bioreactor and equipment}

\section{Glass vessel:}

The glass vessel is a concentric tube reactor (Figure 1B) constructed by Radleys (UK) and comprising a central column (Figure 1A a) with a rounded base and an external glass jacket (Figure 1A b). Two glass 
ports with Duran-type threads are fitted on opposite side (Figure 1A c), one at the bottom and one at the top. The base has a $45 \mathrm{~mm}$ diameter port with a glass Duran-type screw thread (Figure 1A d) for sparger insertion.

A glass draft tube (Figure 1A e) is placed within the central column section. It has two sets of 3 glass lugs near the top and bottom respectively. Silicone tubing is stretched over each lug and used to position the draft tube within the vessel.

\section{Top plate:}

A PTFE top plate (Figure 1C and 1A f) is clamped on top of the glass vessel using a stainless steel clamping ring (Figure 1A g) with a silicone gasket between.

The top plate is perforated by 13 ports:

- a single central port of $12 \mathrm{~mm}$ in diameter (Figure $1 \mathrm{~A} \mathrm{~h}$ ) used to fit a Mettler Toledo gel $\mathrm{pH}$ electrode.

- 2 x 8 mm ports (Figure 1A i) used to fit a PTFE-covered PT100 temperature probe and a glass condenser (Figure 1A i), through which cold water can be passed,

- 8 x $5 \mathrm{~mm}$ ports (Figure 1A k) used for acid and alkali addition; medium feed and culture draw-off; inoculation and sampling system using glass needles or $1 \mathrm{ml}$ glass pipettes. Water and gas tightness is ensured by compression of 5 ring gaskets. When not used, ports are sealed with small glass rods.

\section{Medium/product and alkali/acids bottles:}

Twenty litre Nalgene propylene bottles and $750 \mathrm{ml}$ bottles were used for medium and product or acid and alkali respectively. Screw caps have 3 ports: for delivery, drawing-off and a gas vent fitted with a 0.2 $\mu \mathrm{m}$ PTFE filter. Empty bottles are sterilised by autoclaving and filled 
with either medium or $1 \mathrm{M} \mathrm{HCl}$ or $1 \mathrm{M} \mathrm{NaOH}$ solutions, sterilised beforehand by filtration through $0.2 \mu \mathrm{m}$ Sartobran autoclavable filters (Sartorius). All sterile connections are made using autoclavable quick coupling systems (Cole-Parmer).

Medium and product bottles can be kept under anaerobic conditions if necessary by sparging at a low rate with oxygen-free nitrogen.

\section{Pumps and tubing:}

Masterflex Tygon silicone and Pharmed tubing are used for liquids and gases respectively.

Peristaltic pumps are used for both medium delivery feeding and product draw-off and for alkali or acid feeding. For acid and alkali additions, peristaltic pumps are connected to the $\mathrm{pH}$ regulation system. The feeding pump is a programmable pump, while the product drawoff pump is a standard one.

\section{Controls:}

$\mathrm{pH}$ and temperature are controlled by a 4-20 mA Controller and AFS Biocommand system from New Brunswick (Nijmegen, the Netherlands) associated with a pH transmitter (Broadley James) and a temperature controlled heated circulated bath (Huber). For temperatures up to $95^{\circ} \mathrm{C}$, water can be used for circulation, while mineral oil should be used for temperatures above this. Additionally, the gas lift vessel can be connected to any other standard fermentation control system.

\section{Fermentation protocol}

\section{Medium:}


The basal SME medium (Stetter et al., 1983) was modified according to Sharp and Raven (Raven et al., 1992; Sharp and Raven, 1997) (Table 1) and can be used as it is, or can be modified further for nutritional studies (Raven and Sharp, 1997; Postec et al., 2005b). In this medium, L-cysteine is used as reductant.

\section{Bioreactor set-up:}

Temperature probes, $\mathrm{pH}$ probes (calibrated prior to use) and condensers are positioned in their appropriate ports. All other ports are closed with glass rods. The vessel can be sterilised (with ports closed and covered as appropriate) by placing in an autoclave, but given the fragility of the system, an in situ tyndallisation procedure can also be used: The vessel is filled with distilled water and heated at $100^{\circ} \mathrm{C}$ for 3 hours under aerobic conditions (by sparging the reactor with air) then cooled to room temperature; this procedure is repeated at least 4 or 5 times.

The condenser is then connected to a cold water supply (HS40, Huber refrigerated circulating bath filled with water). Sparging with nitrogen is initiated using a gas flow meter (Aalborg, Monsey, New York) with a 0.2 vol. $\mathrm{vol}^{-1}$. $\mathrm{min}^{-1}$ flow rate. Media feed and product recovery bottles are connected aseptically to the bioreactor and water (used for the sterilisation step of the bioreactor) replaced by medium (at least 5 volume changes are needed). At the same time alkali and acid bottles can be connected aseptically to the bioreactor. A sampling device is also aseptically introduced into the corresponding port.

Temperature and $\mathrm{pH}$ regulation systems are switched on and the $\mathrm{pH}$ value of the medium standardized by measuring the $\mathrm{pH}$ of a small sample by comparison with a standard bench $\mathrm{pH}$ meter at room temperature. The system for continuous culture using the gas lift bioreactor is presented in Figure 2. 


\section{Starting culture:}

When the temperature and $\mathrm{pH}$ have reached their set values, media feed and product draw off pumps are stopped prior to inoculation with a fresh grown vial culture (20 or $40 \mathrm{ml}$ for a 2 litre culture) via the inoculation port.

\section{Culture monitoring:}

The cell density of the culture can be monitored by both direct cell counting using a $0.02 \mathrm{~mm}$ depth Thoma chamber (Weber Scientific International, UK) under a phase contrast microscope or by optical density at $600 \mathrm{~nm}$.

When growth has started, the continuous process can be established by starting both feeding and draw-off pumps. For biomass production, a dilution rate of $0.2 \mathrm{~h}^{-1}$ or $0.4 \mathrm{~h}^{-1}$ is convenient (since from 9.6 to $19.2 \mathrm{l}$ of culture per day are generated). For physiological and nutritional studies, the dilution rate can be lowered in order to obtain at least 3 volume changes in the bioreactor per day. This allows parameter such as $\mathrm{pH}$, temperature and media composition to be altered sequentially each day. with results approximating to equilibrium values being obtained (Raven and Sharp, 1997; Postec et al., 2005b).

\section{Determination of growth parameters}

In addition to steady state cell concentrations, the influence of various parameters (e.g. $\mathrm{pH}$, temperature, gas flow rate or media composition) can also be measured by determination of maximal growth rate under sequentially modified conditions. As previously described (Rinker and 
Kelly, 1996; Rinker et al., 1999) wash out experiments can be performed to determine growth rates according to the formula

$\left[1 / \mathrm{x}(\mathrm{dx} / \mathrm{dt})=\mu_{\max }-\mathrm{D}\right]$

where $\mathrm{x}=$ the cell density of the culture; $\mathrm{t}=$ time; $\mu_{\max }=$ the maximal growth rate, and D is the dilution rate (Duarte et al., 1994), but problems with the reliability of medium delivery rate measurements at high dilution rates $\left(\mathrm{D} \geq 2 \mathrm{~h}^{-1}\right.$ ) have been shown to significantly affect growth rate calculations (personal observation). An alternative method to determine the specific growth rate can be achieved by performing batch culture experiments. A steady state continuous culture under the above culture conditions can be grown at supra-maximal dilution rates in order to lower the cell density significantly. Medium feeding and product draw off are then stopped, and growth under batch conditions followed by regular cell counting (e.g. every 15 min., 3 counts per sample). Growth rate can then be determined by performing a linear regression along the exponential part of the growth curve (Postec et al., 2005b) .

\section{Substrates and metabolic product analysis}

The gas outflow from the bioreactor can be directly analysed using a MTI M200D micro gas chromatograph equipped with a thermal conductivity detector. A Molecular Sieve column with argon as the carrier gas and a temperature of $30^{\circ} \mathrm{C}$ was used to detect $\mathrm{H}_{2}$ and $\mathrm{CO}_{2}$, while $\mathrm{H}_{2} \mathrm{~S}$ was detected using a Poraplot $\mathrm{U}$ column at $100^{\circ} \mathrm{C}$, with helium as the carrier gas.

Substrates (carbohydrates and amino acids) and metabolic end products (organic acids) can be analysed by means of HPLC (Alliance 2690; Waters) as described by Wery et al. (2001). Proteins from the supernatant of the culture are precipitated by a solution of 5- 
sulfosalicylic acid at 2\% (w/v). Amino acids may be analysed after derivatisation (with an ethanol / water / triethylamine / phenylisothiocyanate (7:1:1:1 by vol.) solution) according to the conditions given for the Waters Pico Tag method (WAT007360; Waters). Carbohydrates and linear organic acids are separated on an $\mathrm{H}^{+}$ exclusion column (Polyspher OAKC 1.51270 ; Merck) at $60^{\circ} \mathrm{C}$ with an $18 \mathrm{mM} \mathrm{H}_{2} \mathrm{SO}_{4}$ elution solution $\left(0.35 \mathrm{ml} \mathrm{min}^{-1}\right)$ and detected with a differential refractometer (Refractometer 410, Waters).

\section{FUTURE PROSPECTS: CULTIVATION OF THERMOPHILIC AND HYPERTHERMOPHILIC MICROBIAL COMMUNITIES}

While the gas lift bioreactor was originally developed for culture in the absence of sulphur, it has also been shown to be usable for culture in its presence. Particular care regarding gas exhaust elimination must be taken for safety reasons: hydrogen sulphide is trapped in $10 \mathrm{M} \mathrm{NaOH}$ and the off gas vented to the atmosphere. Cultures in the presence of sulphur should always be performed in well ventilated areas and in the presence of a hydrogen sulphide detector. The utilisation of the gas lift bioreactor has also been shown to be a useful tool for the cultivation of microbial communities in addition to pure cultures from deep sea hydrothermal chimneys.

Continuous enrichment cultures have been performed in the gas lift bioreactor using SME mineral and vitamin solutions added with various organic substrates at $60^{\circ}$ and $90^{\circ} \mathrm{C}$ using a hydrothermal chimney sample as the inoculum. The microbial diversity present was then analysed using molecular tools. Cloning and sequencing of $16 \mathrm{~S}$ rRNA genes of two independent samples from two independent cultures was performed. A denaturing gradient gel electrophoresis (DGGE) analysis of the 16S rRNA gene diversity was also performed over the course of the two cultures in order to monitor the dynamics of the microbial population. The results evidenced quite large diversity 
compared to the diversity previously obtained in the same conditions by classical batch cultures in closed vessels. At $90^{\circ} \mathrm{C}$, while archaeal diversity was limited to species belonging to the Thermococcales, unexpected bacterial diversity was obtained, including still uncultivated species and already described species growing at temperatures above their previously known optimal growth conditions (Postec et al., in press). At $60^{\circ} \mathrm{C}$, considerable bacterial diversity was achieved and both heterotrophic and autotrophic species shown to be cultivated, with some successfully purified and formally described (Postec et al., 2005a). These preliminary experiments indicate that such continuous enrichment cultures in bioreactors may allow (i) access to as yet uncultivated microorganisms and (ii) the co-cultivation of thermophilic microbial deep sea hydrothermal vent species (involved in various biogeochemical cycles) permitting the study of the interactions between species under various experimental conditions with emphasis on better simulating environmental conditions.

\section{ACKNOWLEDGEMENTS}

We thank Ed Hartley from Radleys (England) for providing drawings and pictures of the gas lift bioreactor. We thank Sylvie Gros (Ifremer) for further figures.

\section{REFERENCES}

Adams, M. W. W. (1993). Enzymes and proteins from organisms that grow near and above $100^{\circ} \mathrm{C}$. Ann. Rev. Microbiol. 47, 627-658.

Adams, M. W. W., Holden, J. F., Menon, A. L. Schut, G. J.,Grunden, A. M., Hou, C., Hutchins, A. M., Jenney, F. E., Kim, C., Ma, K. S., Pan, G. L., Roy, R., Sapra, R., Story, S. V.,Verhagen, M (2001). Key role for sulfur in peptide metabolism and in 
regulation of three hydrogenases in the hyperthermophilic archaeon Pyrococcus furiosus. J. Bacteriol. 183, 716-724.

Blöchl, E., Rachel, R., Burggraf, S., Hafenbradl, D., Jannasch, H. W. and Stetter, K. O. (1997). Pyrolobus fumarii, gen. nov., sp. nov., represents a novel group of archaea, extending the upper temperature limit for life to $113^{\circ} \mathrm{C}$. Extremophiles 1, 14-21.

Brown, S. H. and Kelly, R. M. (1989). Cultivation techniques for hyperthermophilic archaebacteria: Continuous culture of Pyrococcus furiosus at temperature near $100^{\circ} \mathrm{C}$. Appl. Environ. Microbiol. 55, 2086-2088.

Canganella, F., Gambacorta, A., Kato, C. and Horikoshi, K. (2000). Effects of hydrostatic pressure and temperature on physiological traits of Thermococcus guaymasensis and Thermococcus aggregans growing on starch. Microbiol. Res. 154, 297-306.

Duarte, L. C., Nobre, A. P., Girio, F. M. and Amaral-Collaço, M. T. (1994). Determination of the kinetic parameters in continuous cultivation by Debaromyces hansenii grown on xylose. Biotechnol. Techn. 8, 859-864.

Erauso, G., Reysenbach, A. L., Godfroy, A., Meunier, J.R., Crump, B., Partensky, F., Baross, J.A.; Marteinsson, V., Barbier, G., Pace, N.R. , Prieur, D.(1993). Pyrococcus abyssi sp. nov. , a new hyperthermophilic archaeon isolated from a deep-sea hydrothermal vent. Arch. Microbiol. 160, 338-349.

Fiala, G. and Stetter, K. O. (1986). Pyrococcus furiosus sp. nov. represents a novel genus of marine heterotrophic archaebacteria growing optimally at $100^{\circ} \mathrm{C}$. Arch. Microbiol. 145, 56-61.

Gantelet, H. and Duchiron, F. (1998). Purification and properties of a thermoactive and thermostable pullulanase from Thermococcus hydrothermalis, a hyperthermophilic archaeaon isolated from deep-sea hydrothermal vent. Appl. Microbiol. Biotechnol. 49, 770-777. 
Godfroy, A., Raven, N. D. H. and Sharp, R. J. (2000). Physiology and continuous culture of the hyperthermophilic deep-sea vent archaeon Pyrococcus abyssi ST549. FEMS Microbiol. Lett. 186, 127-132.

Gonzalez, J. M., Sheckells, D., Viebahn, M., Krupatkina, D., Borges, K. M. and Robb, F. T. (1999). Thermococcus waiotapuensis sp. nov., an extremely thermophilic archaeon isolated from a freshwater hot spring. Arch. Microbiol. 172, 95-101.

Holst, O., Manelius, A., Krahe, M., Markl, H., Raven, N. and Sharp, R. (1997). Thermophiles and fermentation technology. Comp. Biochem. Physiol. 118A, 415-422.

Huber, H., Burggraf, S., Mayer, T., Wyschkony, I., Rachel, R. and Stetter, K. O. (2000). Ignicoccus gen. nov., a novel genus of hyperthermophilic, chemolithoautotrophic Archaea, represented by two new species, Ignicoccus islandicus sp. nov. and Ignicoccus pacificus sp. nov. Int. J. Syst. Evol. Microbiol. 50, 2093-2100.

Kelly, R. M. and Deming, J. W. (1988). Extremely thermophilic archaebacteria: biological and engineering considerations. Biotechnol. Prog. 4, 47-62.

Krahe, M., Antranikian, G. and Märkl, H. (1996). Fermentation of extremophilic microorganisms. FEMS Microbiol. Rev. 18, 217285.

Marteinsson, V. T., Birrien, J. L., Reysenbach, A. L., Vernet, M., Marie, D., Gambacorta, A., Messner, P., Sleytr, U. B. and Prieur, D. (1999a). Thermococcus barophilus sp. nov., a new barophilic and hyperthermophilic archaeon isolated under high hydrostatic pressure from a deep-sea hydrothermal vent. Int. J. Syst.

Bacteriol. 49, 351-359.

Marteinsson, V. T., Reysenbach, A. L., Birrien, J. L. and Prieur, D. (1999b). A stress protein is induced in the deep-sea barophilic 
hyperthermophile Thermococcus barophilus when grown under atmospheric pressure. Extremophiles 3, 277-282.

Miller, J. F., Almond, E. L., Shah, N. N., Ludlow, J. M., Zollweg, J. A., Streett, W. B., Zinder, S. H. and Clark, D. S. (1988). Highpressure-temperature bioreactor for studying pressuretemperature relationships in bacterial growth and productivity. Biotechnol. Bioeng. 31, 407-413.

Miroshnichenko, M. L., Hippe, H., Stackebrandt, E., Kostrikina, A., Chernyh, N. A., Jeanthon, C., Nazina, T. N., Belyaev, S. S. and Bonch-Osmolovkaya, E. A. (2001). Isolation and characterization of Thermococcus sibericus sp. nov. from a Western Siberian high-temperature oil reservoir. Extremophiles 5, 85-91.

Mukhopadhyay, B., Johnson, E. F. and Wolfe, R. S. (1999). Reactorscale cultivation of the hyperthermophilic methanarchaeon Methanococcus jannaschii to high cell densities. Appl. Environ. Microbiol. 65, 5059-5065.

Nelson, C. M., Scuppenhauer, M. R. and Clark, D. S. (1992). Highpressure, high-temperature bioreactor for comparing effects of hyperbaric and hydrostatic pressure on bacterial growth. Appl. Environ. Microbiol. 58, 1789-1793.

Postec, A., Le Breton, C., Fardeau, M. L., Lesongeur, F., Pignet, P., Quérellou, J., Ollivier, B. and Godfroy, A. (2005a). Marinitoga hydrogenitolerans sp. nov., a novel member of the order Thermotogales isolated from a black smoker chimney on the Mid-Atlantic Ridge. Int. J. Syst. Evol. Microbiol. 55, 1217-1221.

Postec, A., Pignet, P., Cueff-Gauchard, V., Schmitt, A., Querellou, J. and Godfroy, A. (2005b). Optimisation of growth conditions for continuous culture of the hyperthermophilic archaeon Thermococcus hydrothermalis and development of sulphur-free defined and minimal media. Res. Microbiol. 156, 82-87.

Postec, A., Urios, L., Lesongeur, F., Ollivier, B., Quérellou, J. and Godfroy, A. (in press). Continuous enrichment culture and 
molecular monitoring to investigate the microbial diversity of thermophiles inhabiting the deep-sea hydrothermal ecosystems. Curr. Microbiol. 50. 138-144

Raffin, J. P., Henneke, G. and Dietrich, J. (2000). Purification and characterization of a new DNA polymerase modulator from the hyperthermophilic archaeon Thermococcus fumicolans. Comp. Biochem. Physiol. Biochem. Mol. Biol. 127, 299-308.

Raven, N., Ladwa, N. and Sharp, R. (1992). Continuous culture of the hyperthermophilic archaeum Pyrococcus furiosus. Appl. Microbiol. Biotechnol. 38, 263-267.

Raven, N. D. H. and Sharp, R. J. (1997). Development of defined and minimal media for the growth of the hyperthermophilic archaeon Pyrococcus furiosus Vc1. FEMS Microbiol. Lett. 146, 135-141.

Rinker, K. D. and Kelly, R. M. (1996). Growth physiology of the hyperthermophilic Archaeon Thermococcus litoralis:

Development of a sulfur-free defined medium, characterization of an exopolysaccharide, and evidence of biofilm formation. Appl. Environ. Microbiol. 62, 4478-4485.

Rinker, K. D. and Kelly, R. M. (2000). Effect of carbon and nitrogen sources on growth dynamics and exopolysaccharide production for the hyperthermophilic Archaeon Thermococcus litoralis and Bacterium Thermotoga maritima. Biotechnol. Bioeng. 69, 537547.

Rinker, K. D., Han, C. J. and Kelly, R. M. (1999). Continuous culture as a tool for investigating the growth physiology of heterotrophic hyperthermophiles and extreme thermoacidophiles. J. Appl. Microbiol. 85 Suppl. S, 118S-127S.

Ronimus, R. S., Reysenbach, A.-L., Musbrave, D. R. and Morgan, H. W. (1997). The phylogenetic position of Thermococcus isolate AN1based on 16S rRNA gene sequence analysis: a proposal that AN1 represents a new species, Thermococcus zilligii, sp. nov. Arch. Microbiol. 168, 245-248. 
Schiaraldi, C., Marulli, F., Di Lernia, I., Martino, A. and De Rosa, M. (1999). A microfiltration bioreactor to achieve high cell density in Sulfolobus solfataricus fermentation. Extremophiles 3, 199204.

Sharp, R. J. and Raven, N. D. H. (1997). Isolation and growth of hyperthermophiles. In: Applied Microbial Physiology: A practical approach (P. M. Rhodes and P. F. Stanbury, Eds), pp. 23-51. IRL Press, Oxford University Press, Oxford.

Stetter, K. O., König, H. and Stackebrandt, E. (1983). Pyrodictium gen. nov., a new genus of submarine disc-shaped sulfur-reducing archaebacteria growing optimally at $105^{\circ} \mathrm{C}$. System. Appl. Microbiol. 4, 535-551.

Wery, N., Lesongeur, F., Pignet, P., Derennes, V., Cambon-Bonavita, M.-A., Godfroy, A. and Barbier, G. (2001). Marinitoga camini, gen. nov., sp. nov., a rod-shaped bacterium belonging to the order Thermotogales, isolated from a deep-sea hydrothermal vent. Int. J. Syst. Evol. Microbiol. 51, 495-504.

Worthington, P., Blum, P., Perez-Pomares, F. and Elthon, T. (2003). Large-scale cultivation of acidophilic hyperthermophiles for recovery of secreted proteins. Appl. Environ. Microbiol. 69, 252257.

\section{LIST OF SUPPLIERS}

\section{Radleys}

Shire Hill, Saffron Walden, Essex CB11 3AZ, UK.

Contact : Ed Hartley, Production Manager

Tel: +44-(0)1799-513320

http://www.radleys.com 
Gas lift bioreactor, temperature probe, condenser, glass needle and sparging assembly

\section{Sigma}

P.O. Box 14508

St Louis, MO 63 178, USA

Tel: 1-800-325-3010

http://www.sigma.cial.com

All chemicals

\section{Difco/BD}

1 Becton Drive

Franklin Lakes, NJ USA 07417

Tel 1-201-847-6800

http://www.difco.com

Peptone, yeast extract

Fisher Scientific International Inc. / Bioblock Fischer Scientific

Liberty Lane

Hampton, NH 03842

Tel: 1-603-926-5911

http://www.bioblock.com

http://www.fisherscientific.com

Pumps and tubing (Masterflex®), quick-coupling system (Cole-

Parmer $\left.{ }^{\circledR}\right)$ and Nalgene ${ }^{\circledR}$ bottles, gas flow meter 


\section{Sartorius AG}

Weender Landstrasse 94-108

D-37075 Göttingen, Germany

Tel: 49-551-308-333

http://www.sartorius.com

Filters

New Brunswick Scientific

PO Box 4005

Edison, NJ USA

Tel: 1-732-287-1200

http://www.nbsc.com

Control system

MTI Analytical Instruments

41762 Christy St.

Fremont, CA 94538, USA

Tel: 1-510-490-0900

Micro Gas Chromatograph

\section{Waters}

34 Maple Street

Milford, Massachusetts 01757, USA

Tel: 1-508-478-2000

http://www.waters.com 
HPLC 
Table 1. Composition of SME medium (Stetter et al., 1983) modified according to Sharp and Raven (Raven et al., 1992; Sharp and Raven, 1997).

\section{Medium}

$\mathrm{NaCl}$

Yeast extract

Peptone

L-cysteine

Resazurine

Magnesium salt solution

Solution A

Solution B

Solution C

Solution D per litre

$28 \mathrm{~g}$

$1 \mathrm{~g}$

$2 \mathrm{~g}$

$0.5 \mathrm{~g}$

$0.5 \mathrm{mg}$

$10 \mathrm{ml}$

$1 \mathrm{ml}$

$1 \mathrm{ml}$

$1 \mathrm{ml}$

$1 \mathrm{ml}$

\section{Stock Solutions}

Magnesium salt solution

\begin{tabular}{ll}
\hline $\mathrm{MgSO}_{4} \cdot 7 \mathrm{H}_{2} \mathrm{O}$ & $180 \mathrm{~g}$ \\
$\mathrm{MgCl}_{2} \cdot 6 \mathrm{H}_{2} \mathrm{O}$ & $140 \mathrm{~g}$
\end{tabular}

Solution A

\begin{tabular}{ll}
\hline $\mathrm{MnSO}_{4} \cdot 4 \mathrm{H}_{2} \mathrm{O}$ & $9 \mathrm{~g}$ \\
$\mathrm{ZnSO}_{4} \cdot 7 \mathrm{H}_{2} \mathrm{O}$ & $2.5 \mathrm{~g}$ \\
$\mathrm{NiCl}_{2} \cdot 6 \mathrm{H}_{2} \mathrm{O}$ & $2.5 \mathrm{~g}$ \\
$\mathrm{AlK}\left(\mathrm{SO}_{4}\right)_{2} \cdot 12 \mathrm{H}_{2} \mathrm{O}$ & $0.3 \mathrm{~g}$ \\
$\mathrm{CoCl}_{2} \cdot 6 \mathrm{H}_{2} \mathrm{O}$ & $0.3 \mathrm{~g}$ \\
$\mathrm{CuSO}_{4} \cdot 5 \mathrm{H}_{2} \mathrm{O}$ & $0.15 \mathrm{~g}$
\end{tabular}


Solution B

\begin{tabular}{ll}
\hline $\mathrm{CaCl}_{2} \cdot 2 \mathrm{H}_{2} \mathrm{O}$ & $56 \mathrm{~g}$ \\
$\mathrm{NaBr}$ & $25 \mathrm{~g}$ \\
$\mathrm{KCl}$ & $16 \mathrm{~g}$ \\
$\mathrm{KI}$ & $10 \mathrm{~g}$
\end{tabular}

Solution C

\begin{tabular}{ll}
\hline $\mathrm{K}_{2} \mathrm{HPO}_{4}$ & $50 \mathrm{~g}$ \\
$\mathrm{H}_{3} \mathrm{BO}_{3}$ & $7.5 \mathrm{~g}$ \\
$\mathrm{Na}_{2} \mathrm{WO}_{4} \cdot 2 \mathrm{H}_{2} \mathrm{O}$ & $3.3 \mathrm{~g}$ \\
$\mathrm{Na}_{2} \mathrm{MoO}_{4} \cdot 2 \mathrm{H}_{2} \mathrm{O}$ & $0.15 \mathrm{~g}$ \\
$\mathrm{Na}_{2} \mathrm{SeO}_{3}$ & $0.005 \mathrm{~g}$
\end{tabular}

Solution D in $1 \mathrm{M} \mathrm{HCl}$

$\mathrm{FeCl}_{2} \cdot 4 \mathrm{H}_{2} \mathrm{O} \quad 10 \mathrm{~g}$

Vitamins solution in ethanol/water (50:50)

\begin{tabular}{ll}
\hline Pyridoxine.HCl & $200 \mathrm{mg}$ \\
Thiamine.HCl & $100 \mathrm{mg}$ \\
Riboflavin & $100 \mathrm{mg}$ \\
Nicotinic acid & $100 \mathrm{mg}$ \\
DL-calcium pantothenate & $100 \mathrm{mg}$ \\
Lipoic acid & $100 \mathrm{mg}$ \\
Biotin & $40 \mathrm{mg}$ \\
Folic acid & $40 \mathrm{mg}$ \\
Cyanocobalamin & $2 \mathrm{mg}$
\end{tabular}




\section{Legends to the figures}

Figure 1. The gas lift bioreactor (A) drawing, (B) picture and (C) top plate.

Figure 2. Schematic diagram of the experimental system for continuous culture with the gas lift bioreactor. (a) $\mathrm{pH}$ probe; (b) $\mathrm{pH}$ controller; (c) acid and alkali bottles; (d) temperature probe; (e) heated circulating bath; (f) sparging assembly; (g) gas flow meter; (h) condenser; (i) condensate trap; (j) gas exhaust; (k) medium bottle; (l) medium pump; (m) product bottle; (n) drawing-off pump; (o) sampling system; and (p) inoculation septum. 


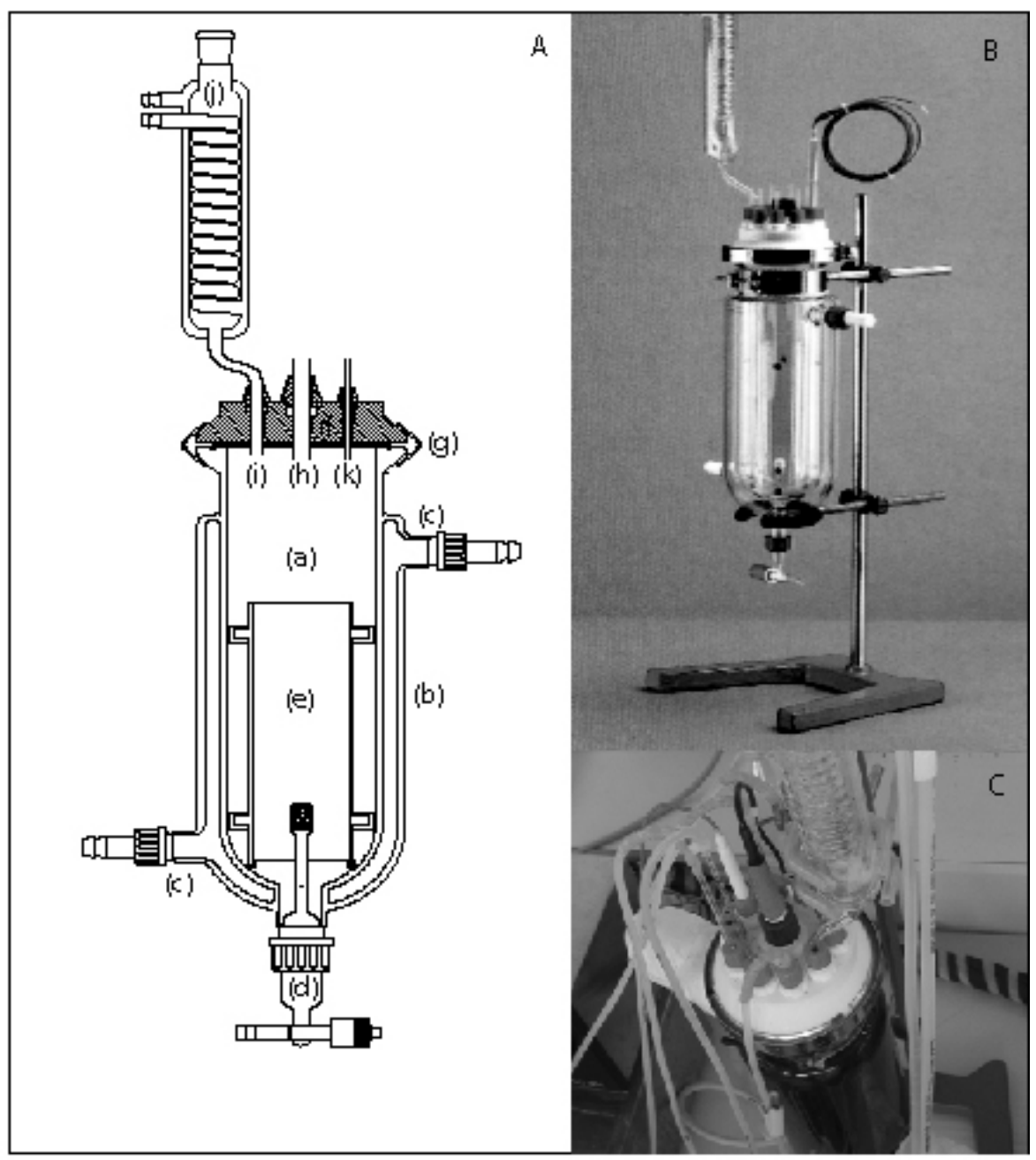






